\title{
Forced commitment promotes attitudinal commitment and trust in an organization
}

\author{
Satoshi Fujii ${ }^{(1)}$ (fujii@plan.cv.titech.ac.jp) \\ Kazuhiro Arai (2) (arai.kazuhiro@nifty.com) \\ [(1) Tokyo Institute of Technology, (2) Hitotsubashi University]
}

\author{
組織における強制的コミットメントによる態度的コミットメントと信頼の醇成 \\ 藤井 聡 ${ }^{(1)}$ 、荒井 一博 (2) \\ (1) 東京工業大学 大学院理工学研究科 \\ (2) 一橋大学 経済学部
}

\begin{abstract}
要約
組織的に対するコミットメント（組織的コミットメント：organizational commitment）と組織内における相互信頼（組 織的信頼 : organizational trust）は、当該組織のパフォーマンスを決定づける重要な要因である。本研究では、組織的コミッ トメントと組織的信頼は、共に、組織内の強制的なコミットメントの存在によって醸成されるであろうとの仮説を設け た。本仮説の検証のために、日本の複数の大学内の「研究室」に所属する158名の学生を対象に、強制的コミットメント、 組織的コミットメント、組織的信頼のそれぞれを測定する調査を実施した。得られた調査データを分析した所、組織的 コミットメントについては、行動的組織的コミットメントと態度的組織的コミットメントの二要因が抽出された。また、 強制的コミットメントについては、各組織の責任者である教授・助教授による強制的コミットメント（個人的強制的コ ミットメント）の程度と、当該組織の活動水準とのものに伴う組織的強制的コミットメントの 2 つを測定した。以上の データを用いて分析した所、本研究の仮説を支持する結果が得られた。すなわち、各組織の責任者である教授・助教授 による強制的な組織的コミットメントない研究室よりもある研究室の構成メンバーの方が、態度的な組織的コミットメ ントと行動的な組織的コミットメントが高くなる事が示された。また、強制性がない組織よりもある組織の方が、研究 室に属する年数が長くなるほど組織的信頼が向上していくことが示された。
\end{abstract}

\section{Key words}

organizational commitment, organizational trust, forced commitment

\section{Introduction}

\subsection{Organizational commitment}

Individuals belong to many organizations, including the workplace, school, residential areas, and their families. An important determinant of an individual's behavior within an organization is organizational commitment (e.g., Mathieu and Zajac, 1990; Mowday, Steers and Poter 1979; Allen and Meyer, 1990; Becker, 1960). With high levels of organizational commitment, individuals work cooperatively to meet the goals of the organization and organizational performance increases. For example, using meta analysis, Riketta (2002) demonstrated that organizational commitment has a significant positive correlation with job performance in the organization.

Many studies have examined the determinants of organizational commitment. The findings of meta analysis by Mathieu and Zajac (1990) indicated that personal characteristics (e.g., age, organizational tenure, perceived or personal competence), job characteristics (job scope or challenge), and group-leader relations (leader communication or participative leadership) were all cor- related to organizational commitment. However, the effects of organizational characteristics on organizational commitment have not been well investigated. Although Bateman and Strasser (1984), Morris and Streers (1980) and Stevens and Trice (1978) reported correlations between organizational centralization and organizational commitment, the correlations were not consistent, and consequently, the average correlations in the meta analysis performed by Mathieu and Zajac (1990) were not significant. Another organizational characteristic investigated was organizational size, but the meta analysis also indicated no significant correlation with organizational commitment.

Thus, the effects of organizational characteristics on organizational commitment are not well understood, as argued, for example, by Mathieu and Zajac (1990) and Takagi (2003). In this study, we focus on a specific organizational characteristic that may determine organizational commitment, i.e., forced commitment. Forced commitment refers to the extent to which organizational members are forced to engage in certain behaviors, regardless of their willingness. Organizations that hold frequent meetings or have required organizational activities are regarded as having high levels of forced commitment. If the level of forced commitment in an organization is high, members are required to engage in certain types of pro-organizational behavior. According to cognitive 
dissonance theory, or a discussion about organizational behavior by Kiesler (1971) based on the theory, such pro-organizational behavior may have a positive effect on an individual's attitudes towards the organization, even though the behavior was required by the organization. In this study, we hypothesize that forced commitment by organizations has a positive effect on organizational commitment. One of the purposes of the current study is to test this hypothesis.

\subsection{Organizational trust}

Organizational trust, defined in this study as trust between organizational members, is another important variable that influences the organizational behavior of group members (Kramer and Tyler, 1996). If organizational members did not trust the other members at all, they could not ask for help from or cooperate with other members in performing the jobs within the organization (Miller, 2001). Organizational performance would decrease markedly without organizational trust. Therefore, organizational trust is indispensable for the effective performance of an organization.

Stolle (2001) investigated the determinants of organizational trust. On the basis of a cross-country analysis, he reported that organizational trust was influenced by personal characteristics and the type of organization, but was not correlated with organizational tenure. He found that organizational trust increased in the length of membership for individuals in a church organization but not for individuals in other non-work organizations, such as a bowling club. However, the data did not indicate why the type of organization would have an effect on organizational trust. Tyler (2001) and Tyler and Degoey (1996) also discussed trust among individuals in an organization, but the main focus in these studies was trust toward the authorities in an organization. Powell (1996) examined the development of trust and assumed that trust among individual members in an organization was related to the communication between them; however, he did not provide empirical evidence to support his assumption. Several other studies (Kramer and Tyler, 1996; Cook, 2001) also examined issues of trust, but the organizational characteristics that determine it were not well understood.

The current study again focuses on forced commitment as a possible determinant of organizational commitment. In an organization with high levels of forced commitment, every member typically meets the other members frequently, and they are obliged to cooperate with each other for organizational purposes. Through this obliged or forced cooperation, organizational members may come to believe that the other members are trustworthy, despite the fact that the cooperation is required by the organization. On the other hand, members in an organization with lower levels of forced commitment may have fewer opportunities to meet and cooperate with other members, and consequently, fewer opportunities to develop a sense of trustworthiness regarding the other members. Our hypothesis is that organizational forced commit- ment promotes the development of trust between organizational members. This hypothesis is in line with the finding of Burt and Knez (1996) that more social relationships with other people leads to greater trust in others, although their data did not address trust between members in an organization. Testing this hypothesis with respect to organizational trust is another purpose of the current study in addition to testing it with respect to organizational commitment.

\section{Methods}

To test the hypothesis of the effect of forced commitment, it is necessary to collect data from organizations with low and high levels of forced commitment. Previous studies have typically investigated work-related organizations, which usually have a high degree of forced commitment, as members are generally hired, commute, and work every weekday. Others have compared organizational trust and attitudinal commitment for different types of organizations, such as work organizations compared to non-work organizations, and religious organizations compared to leisure organizations, as in the study by Stolle (2001). However, this leaves open the possibility that differences in effects of organizational trust and commitment between different types of organizations may reflect the influence of other uncontrolled variables. In this study, we conducted a survey targeting at undergraduate and graduate students in university laboratories, a type of organization that has a lower level of forced commitment than work organizations, as members are not typically hired, and are not always obliged to commute or to do research and study every day. Some laboratories may have higher levels of forced commitment for the purpose of research production, suggesting that the university laboratory organization will be suitable for research regarding varying degrees of forced commitment.

\subsection{Sample}

One hundred and sixty-nine undergraduate and Master's degree program students associated with research laboratories in the Departments of Engineering at Kyoto University, Tokyo Institute of Technology, Hokkaido University, and Hokkai Gakuen University were asked to complete a questionnaire. In all these universities, students usually study for 4 years as undergraduate students and enter a laboratory during their fourth year to complete a fourth year thesis. The laboratory typically consists of a professor, who supervises the thesis research, and approximately 10 to 20 students. Each student usually has his/her own desk in a laboratory. Most undergraduate students in the Department of Engineering continue on to the Master's degree program after finishing the fourth year thesis, and usually continue studying and researching in the same laboratory. After completing the Master's degree program in two years, some enroll in the Doctoral degree program, but most students leave to obtain employment. Of the 169 respondents, 65 were undergraduate students and 104 were Master’s pro- 
gram students. Fifty-four of the undergraduates planned to continue to the Master's degree program. Data from the eleven students who did not plan to continue were eliminated from analysis, because they would only stay in their laboratories for one year. The mean age of the 158 remaining participants was 22.92 years (SD $=1.44$ ), and $91.8 \%$ (145) were male (Note that since the ratio of male in the Department of Engineering in these universities were high, this ratio did not substantially deviate from the population at all.). All participants had their own desk, and 83.5\% (132) had their own personal computer on their desk. The mean tenure in the laboratory at the time of the survey was 15.22 months (SD = 13.60 months).

\subsection{Measures}

The questionnaire contained items concerning social values, general trust, personal attributes, and the laboratory in the university. Only responses to questions associated with the laboratory were used for testing the hypothesis.

To assess forced commitment, we measured two variables: organizationally forced commitment (OFC), which denotes commitment required by the organization, and professorially forced commitment (PFC), which denotes commitment required by the professor, the leader of the organization. For organizationally forced commitment, respondents judged the frequency of formal organizational activities by choosing from "no. of times per week," "no. of times per month" or "no. of times per year" and adding a numerical estimate in response to the question, "How frequently are there activities, such as research meetings or formal parties, in your laboratory?” The mean frequency was 0.92 activities per week $(\mathrm{SD}=0.85)$. The minimum frequency was 0.038 per week (twice a year) and the maximum was 5.98 per week (312 times a year). For professorially forced commitment, participants were asked about the frequency of having a meal with their professor.
This seems an appropriate measure of professorially forced commitment, as the decision for students and their professors to have a meal together would likely reflect a personal decision made by the professor rather than personal decisions made by students, as implied by a study about the relation between formal and informal organizations (Roethlisberger and Dickson, 1938; Davis, 1953). The informal "meeting” of having a meal together might still be considered obligatory, albeit less so than a formal activity organized for the laboratory members. Participants rated their level of agreement with the statement, "I frequently have a meal with my professor" on a nine-point scale, ranging from "no, not at all” to "yes, exactly." The mean was 4.26 and the standardized deviation was 2.43 .

We predict that frequency of organizationally forced commitment, as measured by the frequency of formal organizational activities, will be more strongly related to organizational trust than to organizational commitment, because formal organizational activities likely involve obligatory cooperative behavior between organizational members, and the experience of observing other group members cooperating would promote feelings of trustworthiness (Hardin, 2001). Furthermore, we suggest that professorially forced commitment, as measured by the frequency of having a meal with the professor, is more strongly related to organizational commitment than to organizational trust, partly because the leader in an organization symbolizes the organization as implied by the group value model (Lind and Tyler, 1988; Tyler, 2001), and partly because communication with an individual is likely to promote a positive attitude towards that individual due to the effects of exposure (Zajonc, 1968) or the motivation to reduce cognitive dissonance between attitude and behavior (Festinger, 1957; Kiesler, 1971). That is, communication with a professor is likely to promote a positive attitude towards the professor, which in turn increases organizational commitment. In addition, communication

Table 1: Results of principal component analysis of organizational commitment and organizational trust, and means (M) and standard deviation of each measurement

\begin{tabular}{|c|c|c|c|c|c|}
\hline & \multirow{2}{*}{\multicolumn{3}{|c|}{$\begin{array}{l}\text { Factor loadings in principal } \\
\text { component analysis } \\
\text { Factor } 1 \text { Factor } 2 \text { Factor } 3\end{array}$}} & \multicolumn{2}{|c|}{ Descriptives } \\
\hline & & & & \multirow{2}{*}{$\frac{\mathrm{M}}{6.38}$} & \multirow{2}{*}{$\frac{\mathrm{SD}}{1.92}$} \\
\hline I like the professor(s) in my laboratory. & 0.89 & -0.06 & 0.05 & & \\
\hline I am proud of the research in my laboratory. & 0.85 & 0.04 & 0.19 & 6.07 & 2.12 \\
\hline I am proud of the professor(s) in my laboratory. & 0.86 & 0.15 & 0.04 & 6.63 & 1.97 \\
\hline I am interested in the research in my laboratory. & 0.81 & 0.08 & 0.21 & 6.30 & 2.17 \\
\hline I respect the professor(s) in my laboratory. & 0.79 & 0.09 & 0.07 & 7.04 & 1.84 \\
\hline I like my laboratory. & 0.68 & 0.28 & 0.18 & 6.54 & 2.04 \\
\hline The goals of my laboratory are my own goals as well. & 0.47 & 0.14 & 0.57 & 4.97 & 2.21 \\
\hline I am happy to perform tasks asked of me by the professor(s) or other laboratory members. & 0.25 & 0.17 & 0.67 & 6.20 & 1.94 \\
\hline I think it is normal for laboratory members to have to clean up the laboratory. & 0.08 & -0.08 & 0.57 & 7.11 & 1.96 \\
\hline I am happy to help other laboratory members in need. & 0.04 & 0.38 & 0.77 & 6.90 & 1.67 \\
\hline I am happy to teach other junior laboratory members. & 0.03 & 0.27 & 0.78 & 6.75 & 1.62 \\
\hline The laboratory members are trustworthy. & 0.11 & 0.81 & 0.14 & 7.02 & 1.88 \\
\hline The laboratory members would help me if I was in need. & 0.17 & 0.76 & 0.27 & 7.01 & 1.69 \\
\hline The laboratory members are good and kind. & 0.15 & 0.81 & 0.04 & 7.47 & 1.49 \\
\hline The laboratory members are honest. & 0.03 & 0.78 & 0.11 & 7.04 & 1.87 \\
\hline The laboratory members never bother me. & 0.02 & 0.78 & 0.12 & 7.46 & 1.57 \\
\hline Contribution rate & $36.3 \%$ & $18.6 \%$ & $9.8 \%$ & - & - \\
\hline Accumulated contribution rate & (36.3\%) & (54.9\%) & (64.7\%) & - & - \\
\hline
\end{tabular}


with the leader may increase the perception of the procedural justice of the organization, and the perceived procedural justice may, in turn, promote a positive attitude toward the organization (Lind and Tyler, 1988). In the meta analysis by Mathieu and Zajac (1990) communication with the leader had the second largest positive correlation with organizational commitment among 26 antecedents of organizational commitment.

Organizational commitment and organizational trust were measured using the 16 statements listed in Table 1. Participants responded using a 9-point semantic scale the endpoints of which were "no, not at all” and "yes, exactly."

\section{Results}

\subsection{Measures}

A principal component analysis produced Table 1, which shows that $64.7 \%$ of the total variance of the 16 variables was explained by three components. Attitudinal organizational commitment (attitudinal OC) consists of variables whose factor loadings for the first component were high ("I like the professor(s) in my laboratory," "I am proud of the research in my laboratory," "I am proud of the professor(s) in my laboratory," "I am interested in the research in my laboratory," "I respect the professor(s) in my laboratory," "I like my laboratory," and “The goals of my laboratory are my own goals as well”). These 7 ratings were added to give a single measure of attitudinal OC. The Cronbach's $\alpha$ of this measure was 0.90 . The average was $43.9(\mathrm{SD}=11.3)$. Organizational trust (OT) consists of variables the factor loadings of which on the second factor were high ("The laboratory members are trustworthy," "The laboratory members would help me if I was in need," "The laboratory members are good and kind," "The laboratory members are honest," and "The laboratory members never bother me”). These 5 ratings were summed to give a single measure of
OT. The Cronbach's $\alpha$ of this measure was 0.86 . The average was $36.0(\mathrm{SD}=6.9)$. Behavioral organizational commitment (behavioral OC) designates the third component, which had high factor loadings for "I am happy to perform tasks asked of me by the professor(s) or other laboratory members," "I think it is normal for laboratory members to have to clean up the laboratory," "I am happy to help other laboratory members in need," and "I am happy to teach other junior laboratory members.” These 4 ratings were added to give a single measure of behavioral OC. The Cronbach's $\alpha$ of this measure was 0.72 . The average was 26.9 $(\mathrm{SD}=5.3)$. In summary, the analysis resulted in two measures of organizational commitment and a measure of organizational trust. Note that the distinction between behavioral OC and attitudinal OC in this study is similar to that proposed by Mowday, Steers, and Poter (1979).

\subsection{Effects of forced commitment}

To investigate the effects of forced commitment on attitudinal OC, behavioral OC, and OT, analysis of variance (ANOVA) was performed, with tenure in the laboratory, frequency of having a meal with the professor, and frequency of formal organizational activities as independent variables. Tenure in the laboratory was included because forced commitment may require time to influence the dependent variables used in this study. If the effect of forced commitment requires a long time in the laboratory, we expect a significant interaction between forced commitment and tenure in the laboratory. However, if the effects of forced commitment develop over a short time, we expect only a main effect of forced commitment.

Table 2 shows the means (M) and standard deviations (SD) of attitudinal OC, behavioral OC, and OT for tenure in the laboratory, the frequency of formal organizational activities, and the fre-

Table 2: Means (M) and standard deviations (SD) of attitudinal OC, behavioural OC, and OT for organizational tenure, organizationally forced commitment (OFC), and professorially forced commitment (PFC)

Tenure in laboratory

\begin{tabular}{|c|c|c|c|c|c|c|c|c|c|}
\hline & & & less $t$ & 1 year & & & $1 \mathrm{ye}$ & more & \\
\hline & & & & & & & & & \\
\hline & & hig & & & & & & & \\
\hline & & $\mathrm{PF}$ & & & & & & & \\
\hline & & low l & high & low & high & low & high & low & high \\
\hline & & $\overline{(15)^{\dagger}}$ & (14) & (23) & (16) & (14) & (27) & (20) & (28) \\
\hline attitudinal OC & $\begin{array}{c}\mathrm{M} \\
(\mathrm{SD})\end{array}$ & $\begin{array}{c}37.2 \\
(13.4)\end{array}$ & $\begin{array}{l}44.8 \\
(6.1)\end{array}$ & $\begin{array}{c}37.0 \\
(11.1)\end{array}$ & $\begin{array}{c}39.3 \\
(10.6)\end{array}$ & $\begin{array}{c}35.1 \\
(11.6)\end{array}$ & $\begin{array}{l}42.6 \\
(6.4)\end{array}$ & $\begin{array}{c}35.4 \\
(10.1)\end{array}$ & $\begin{array}{l}39.3 \\
(8.7)\end{array}$ \\
\hline behavioral OC & $\begin{array}{c}\mathrm{M} \\
(\mathrm{SD})\end{array}$ & $\begin{array}{l}29.1 \\
(7.7)\end{array}$ & $\begin{array}{l}33.6 \\
(5.3)\end{array}$ & $\begin{array}{l}32.5 \\
(4.8)\end{array}$ & $\begin{array}{l}35.0 \\
(5.5)\end{array}$ & $\begin{array}{l}29.4 \\
(7.7)\end{array}$ & $\begin{array}{l}31.9 \\
(8.9)\end{array}$ & $\begin{array}{l}29.1 \\
(6.5)\end{array}$ & $\begin{array}{l}33.6 \\
(5.0)\end{array}$ \\
\hline OT & $\begin{array}{c}\mathrm{M} \\
(\mathrm{SD})\end{array}$ & $\begin{array}{l}35.1 \\
(7.9)\end{array}$ & $\begin{array}{l}36.1 \\
(5.9)\end{array}$ & $\begin{array}{l}36.2 \\
(6.6)\end{array}$ & $\begin{array}{l}38.8 \\
(4.7)\end{array}$ & $\begin{array}{l}36.5 \\
(8.5)\end{array}$ & $\begin{array}{l}37.6 \\
(6.1)\end{array}$ & $\begin{array}{l}33.0 \\
(7.6)\end{array}$ & $\begin{array}{l}34.8 \\
(7.0)\end{array}$ \\
\hline
\end{tabular}


quency of having a meal with the professor. The median frequency of formal organizational activities was used to divide the data into 2 groups: those with a high frequency of organizationally forced commitment (high OFC group) and those with lower levels of organizationally forced commitment (low OFC group). Similarly, the median frequency of having a meal with the professor was used to form two groups: the high professorially forced commitment group (high PFC group) and the low professorially forced commitment group.

We performed a 2 (less than 1 year of tenure vs. 1 year or more) $\times 2$ (high vs. low OFC group) $\times 2$ (high vs. low PFC group) ANOVA for the three dependent variables. We found no significant main effects of tenure in the laboratory on attitudinal OC, behavioral OC, or OT. We found significant main effects of PFC on attitudinal OC $(F[1,149]=13.73, p<.001)$ and behavioral OC $(F[1,149]=5.76, p=.018)$. As evident from Table 2, the means for attitudinal and behavioral OC for the high-PFC group were greater than those for the low-PFC group, regardless of OFC and regardless of tenure. These results support the hypothesis that the frequency of organizationally forced commitment has a positive effect on organizational commitment. However, PFC did not have a significant effect on OT. There were also no significant interaction effects between PFC and tenure for any of the dependent variables. The implication of these observations is that the effect of informal forced commitment did not require a long time to emerge.

With respect to OFC, we found a significant interaction effect with tenure on OT $(F[1,149]=4.85, p=.029)$. As is evident from Table 2, while for high OFC the mean OT for the group with tenure of 1 year or more was larger than for the group with tenure of less than 1 year, for low OFC the means for OT for the group with tenure of 1 year or more were smaller than those for the group with tenure of less than 1 year. The main effect of OFC on OT was not significant. These results imply that OFC promotes OT, but it requires a longer time to do so. There were also no significant effects of OFC on attitudinal OC or behavioral OC, and there were no interaction effects.

\section{Discussion}

We hypothesized that forced organizational commitment would promote organizational trust and organizational commitment in members of university laboratory organizations, a type of organization that was expected to vary in levels of forced commitment to a greater extent than work organizations. Professorially forced commitment, as measured by informal activities within the laboratory, was expected to promote organizational commitment. Communication with a professor may promote a positive attitude toward the professor, who is the leader of the organization (Festinger, 1957; Kiesler, 1971; Zajonc, 1968) and is expected to symbolize the organization (Lind and Tyler, 1988; Tyler, 2001). We also predicted that organizationally forced commitment would be strongly related to organizational trust, as the experiences required by the obligations of the organization would allow members to see that the other members were cooperative, and would lead them to believe that the other members were trustworthy.

The results using data supported both hypotheses. Professionally forced commitment showed significant positive effects on attitudinal organizational commitment and on behavioral organizational commitment, and organizationally forced commitment had an interaction effect with tenure in the laboratory on organizational trust. There are two implications of these results. The first is that organizational trust develops gradually in an environment with high levels of forced organizational commitment, such as an environment where there are frequent formal organizational activities. It is possible that the interaction effect between tenure and organizationally forced commitment could result if students with high levels of organizational trust tended to stay longer in the laboratory, producing a positive relationship between tenure and organizational trust. However, as we selected only undergraduate students who planned to complete Master's programs and eliminated those who had no plans to do so from the sample, the interaction effect cannot be explained simply by the effect of organizational trust on tenure. Therefore, the interaction indicates that organizational trust increases in organizations with high organizationally forced commitment, as was hypothesized.

The second implication of our results using data is that professorially forced commitment, such as having a meal with the professor, immediately fosters organizational commitment. This second implication supports our hypothesis and is in line with the results of the meta analysis reported by Mathieu and Zajac (1990). However, it is also possible that group members who had high levels of organizational commitment tended to be those who had a meal with their professors. Our assumption was that the collective decision to have a meal together would be primarily influenced by a personal decision by the professor rather than decisions by students. If this assumption was not unrealistic, then the implication that professorially forced commitment promotes organizational commitment is reasonable.

The data support our hypothesis that forced commitment promotes organizational commitment and organizational trust. However, it is difficult to conclude that stronger forced commitment always leads to greater organizational commitment and organizational trust. In developing the hypotheses, we made two assumptions. That is, we assumed that experiences to see others cooperating would help promote trust among members, and that experiences to be with a leader would have a positive effect on organizational commitment. The university laboratory environment from which we obtained our sample was expected to be less coercive than a work organization. Consequently, we cannot predict with certainty that the results of this study would apply in a more coercive organization. Our study did not address levels of commitment within organizations with high levels of forced commitment, 
e.g., 12 hours forced work every day for 6 working days per week, as compared to 8 hours every day for 5 working days per week. Similarly, the question of whether organizational commitment is higher in an organization where dinner with the leader is a nightly occurrence than in an organization where members are asked to have dinner with the leader once a week remains unanswered. Very strong levels of forced commitment might have effects opposite to those found in this study, as implied by psychological reactance theory (Brehm, 1966) or the discussion by Yamagishi and Yamagishi (1994).

However, our findings suggest that organizations without any forced commitment or any organizational norms (Allen and Meyer, 1990; Wiener, 1982) may fail to develop attitudinal organizational commitment, behavioral organizational commitment, or trust among members, and subsequently would fail to accomplish their goals effectively. Some level of forced commitment in an organization is necessary to promote organizational commitment and trust among group members, which is, in turn, expected to increase organizational performance. The question of what is an appropriate type and level of forced commitment for developing organizational commitment and trust remains a direction for future research.

\section{References}

Allen, N. J. and Meyer, J. P. (1990). Organizational socialization tactics: a longitudinal analysis of links to newcomers' commitment and role orientation. Academy of Management Journal, 33, 1379-1390.

Bateman T. S. and Strasser, S. (1984). A longitudinal analysis of the antecedents of organizational commitment. Academy of Management Journal, 27, 95-112.

Becker, H. S. (1960). Notes on the concept of commitment. American Journal of Sociology, 66, 32-40.

Brehm, J. (1966). Explorations in Cognitive Reactance. Academic Press, New York.

Burt, R. S. and Knez, M. (1996). Trust and third-party gossip. In T. R. Tyler and R. M. Kramer (Eds.) Trust in Organizations, Saga Publications Inc., California, pp. 51-67.

Cook, K. S. (2001). Trust in Society. Russell Sage Foundation, New York.

Davis (1953). Management communication and grapevine. Harvard Business Review, 31, 43-49.

Festinger, L. (1957). A Theory of Cognitive Dissonance. Stanford University Press.

Hardin, R. (2001). Conceptions and explanations of trust. In Cook, K. S. (Ed.) Trust in Society, Russell Sage Foundation, New York.

Kiesler, C. A. (1971). The Psychology of Commitment: Experiments Linking Behavior to Belief. Academic Press. New York.

Kramer, R. M. and Tyler, T. R. (1996). Trust in Organizations. Saga Publications Inc., California.

Mowday, R. T., Steers R. M. and Poter, L. W. (1979). The mea- surement of organizational commitment, Journal of Vocational Behavior, 14, 224-247.

Mathieu, J. E. and Zajac, D. M. (1990). A review of meta-analysis of the antecedents, correlates, and consequences of organizational commitment. Psychological Bulletin, 108 (2), 171-194. Miller, G. (2001). Why is trust necessary in organizations? The moral hazard of profit maximization. In K. S. Cook (Ed.), Trust in Society, Russell Sage Foundation, New York, pp. 307-331.

Morris J. H. and Streers R. M. (1980). Structural influences on organizational commitment. Journal of Vocational Behavior, $17,50-57$.

Lind, E. A. and Tyler, T. R. (1988). The Social Psychology of Procedural Justice. Plenum, New York.

Powell (1996). Trust-based forms of governance. In T. R. Tyler and R. M. Kramer (Eds.) Trust in Organization, Saga Publications Inc., California, pp. 51-67.

Riketta, M. (2002). Attitudinal organizational commitment and job performance: a meta analysis. Journal of Organizational Behavior, 23, 257-266.

Roethlisberger, F. J. and Dickson W. J. (1938). Management and the Worker. Harvard University Press.

Stevens, J. M. Beyer, J. and Trice, H.M. (1978). Assessing personal, role, and organizational predictors of managerial commitment. Academy of Management Journal, 21, 380-396.

Stolle, D. (2001). Clubs and congregations: The benefits of joining an association. Trust in Society, Russell Sage Foundation, New York, pp. 202-244.

Takagi, H. (2003). Organizational commitment as multidimensional concept: an examination of antecedents and outcomes. Japanese Journal of Social Psychology, 18 (3), 156-171. (Japanese with English abstract)

Tyler, T. R. (2001). Why do people rely on others? Social identity and social aspects of trust. Trust in Society, Russell Sage Foundation, New York, pp. 285-306.

Tyler, T. R. and Degoey, P. (1996). Trust in organizational authorities: the influence of motive attributions on willingness to accept decisions. In T.R. Tyler and R.M. Kramer (Eds.) Trust in Organization, Saga Publications Inc., California, pp. 331356.

Tyler, T. R. and Kramer, R. M. (1996). Whither Trust? In T.R. Tyler and R.M. Kramer (Eds.) Trust in Organization, Saga Publications Inc., California, pp. 1-16.

Wiener, Y. (1982). Commitment in organizations: A normative view. Academy of Management Review, 7, 687-690.

Yamagishi, T. and Yamagishi, M. (1994). Trust and commitment in the United States and Japan. Motivation and Emotion, 18 (2), 129-166.

Zajonc, R. B. (1968). Attitudinal effects of mere exposure. Journal of Personality and Social Psychology, Monograph Supplement, 9(2), 1-27.

(Received July 24, 2005; accepted August 29, 2005) 